Article

\title{
Amazonian BC contribution to the Vallunaraju glacier surface melt
}

\author{
Wilmer Sánchez $1,3,{ }^{*}$, Carl Schmitt ${ }^{2}$, Alexzander Santiago ${ }^{3}$ and Gerles Medina ${ }^{4}$ \\ American Climber Science Program, Colorado; wsanchezr@unasam.edu.pe \\ University of Alaska, Fairbanks; schmitt.carlg@gmail.com \\ Universidad Nacional Santiago Antúnez de Mayolo, Huaraz; asantiagom@unasam.edu.pe \\ Universidad Nacional de Ingeniería, Lima; gmedinao@uni.pe \\ * Correspondence: wsanchezr@unasam.edu.pe; Tel.: +51-995590445
}

\begin{abstract}
The role of Black Carbon (BC) as a contributor to glacial retreat is of particular interest to the scientific community and decision makers, due to its impact on snow albedo and glacier melt. In this study, a thermal-optical instrument (LAHM) was used to measure effective Black Carbon (eBC) in a series of surface snow samples collected from the Vallunaraju glacier, Cordillera Blanca, between April 2019 and May 2020. The time series obtained indicates a marked seasonal variability of $\mathrm{eBC}$ with maximum concentrations during the dry season and dramatic decrease during the wet season. The concentrations detected ranged between a minimum of $3.73 \mathrm{ng} / \mathrm{g}$ and $4.23 \mathrm{ng} / \mathrm{g}$ during the wet season and a maximum of $214.13 \mathrm{ng} / \mathrm{g}$ and $181.60 \mathrm{ng} / \mathrm{g}$ during the dry season, in the accumulation and ablation zone. Using SNICAR model, the reduction of albedo was estimated at $6.36 \%$ and $6.60 \%$ during the dry season and $0.68 \%$ and $0.95 \%$ during the wet season, which represents an average radiative forcing of $4.52 \pm 1.84 \mathrm{~W} / \mathrm{m}^{2}$ and $4.69 \pm 1.59 \mathrm{~W} / \mathrm{m}^{2}$ in the accumulation zone, and $0.49 \pm 0.27 \mathrm{~W} / \mathrm{m}^{2}$ and $0.68 \pm 0.43 \mathrm{~W} / \mathrm{m}^{2}$ in the ablation zone. The melting of snow due to the eBC translates into $80.18 \pm 37.30 \mathrm{~kg} / \mathrm{m}^{2}$ and $83.16 \pm 32.75 \mathrm{~kg} / \mathrm{m}^{2}$ during the dry season, and 7.91 $\pm 4.29 \mathrm{~kg} / \mathrm{m}^{2}$ and $10.85 \pm 6.62 \mathrm{~kg} / \mathrm{m}^{2}$ during the wet season, in the accumulation and ablation zones, respectively. Finally, the HYSPLIT trajectory assessment shows that aerosols predominate in the Amazon rainforest, especially when forest fires are most abundant according to VIIRS images.
\end{abstract}

Keywords: black carbon; snow; albedo; glaciers; trajectories, Vallunaraju

\section{Introduction}

Black Carbon (BC), commonly called "soot", is an air pollutant that is produced by the incomplete combustion of fossil fuels, biofuels and biomass. BC is comprised of microscopic solid particles $\left(<\mathrm{PM}_{2.5}\right)$. The main characteristic of $\mathrm{BC}$ is its high capacity to absorb light, particularly in the visible spectrum $[1,2,3]$. In recent decades the scientific community has paid more interest to black carbon and its impacts on the climate system, especially the negative effects BC has on glaciers $[4,5$, $6,7]$.

Tropical glaciers are particularly vulnerable to BC deposition [8, 9], because South America is one continents with the highest emission of $\mathrm{BC}$. The rapid increase in urban transport, the burning of agricultural residues, forest fires, and the use of biomass for cooking in rural households are the most common sources of BC in the Andean region. A significant contribution of BC to the Andean ice comes from smoke and ash from forest fires in the Amazon rainforest, being transported up the mountains to be deposited on the snow $[8,10]$. BC promotes early seasonal snow melt, which in turn causes runoff water deficits during the dry season. This will become a serious problem for the future fresh water supply in the Andes, which will not meet the greater demand [11]. Additionally, an increase of $\sim 2.5^{\circ} \mathrm{C}$ is projected in the Andean region at the end of this century [12], which would lead to a higher melting rate.

Since the 1970s, the glaciers of the Cordillera Blanca have melted significantly [11]. The main cause being the increase in global temperature, due to climate change. However, there are other 
factors that contribute to the accelerated retreat of glaciers. One of them is the deposition of BC particles on the glacier surface, which cause a decrease in the albedo of the snow [13]. This process is called positive radiative forcing, where the heating of the snow promotes, faster melting. Although BC concentrations have been measured in ice cores in various studies $[14,15,16]$, there are few measurements of $\mathrm{BC}$ in snow surface area that covers a glacier for an annual period. This is crucial to assess in glaciers close to large cities, since local BC emissions are more significant compared to emissions further afield, and we can start to understand the relationship between $\mathrm{BC}$, policies affecting $B C$ production, and glacier pollution.

Based on periodic sampling, eBC concentrations have previously been reported in the glaciers of the Cordillera Blanca from 2011 to 2013 [17]. Subsequently, the eBC was assessed monthly in four glaciers of the Cordillera Blanca for a period of two years [18]. The results indicate that glaciers close to large urban populations are more prone to greater BC deposition on snow. Presented here, $\mathrm{eBC}$ in the snow of the Vallunaraju glacier was measured on a monthly basis for one year using the Light Absorption Heating Method (LAHM). The reduction in albedo estimated with the SNICAR model, was used to calculate the amount of snow that melted as a result of BC. Finally, the provenance of BC was evaluated using the Hybrid Single Particle Lagrangian Integrated Trajectory (HYSPLIT) [19, 20] model based on the number of forest fires in South America provided by the Visible Infrared Imaging Radiometer Suite (VIIRS) [21].

\section{Experiment}

\subsection{Sampling Site}

The study was conducted on the western flank of the Vallunaraju Glacier $\left(9^{\circ} 25^{\prime} \mathrm{S}, 77^{\circ} 27^{\prime} \mathrm{W}, 5686\right.$ $\mathrm{m}$ a.s.l.) located in the Cordillera Blanca, Ancash, Peru (Figure 1). This glacier is characterized by its proximity to the city of Huaraz (capital of the region).

Twelve samples were collected from monthly expeditions between April 2019 and May 2020. The field work consisted of collecting surface snow in both the glacier accumulation and ablation zones, maintaining the same sampling site frequently. Snow samples were collected inside sealed bags, taking care not to contaminate the snow with the climbing material. Subsequently, the snow was melted in a container with hot liquid water and filtered using $0.7 \mu \mathrm{m}$ porosity quartz filters. Filters were air dried and preserved until analysis. 


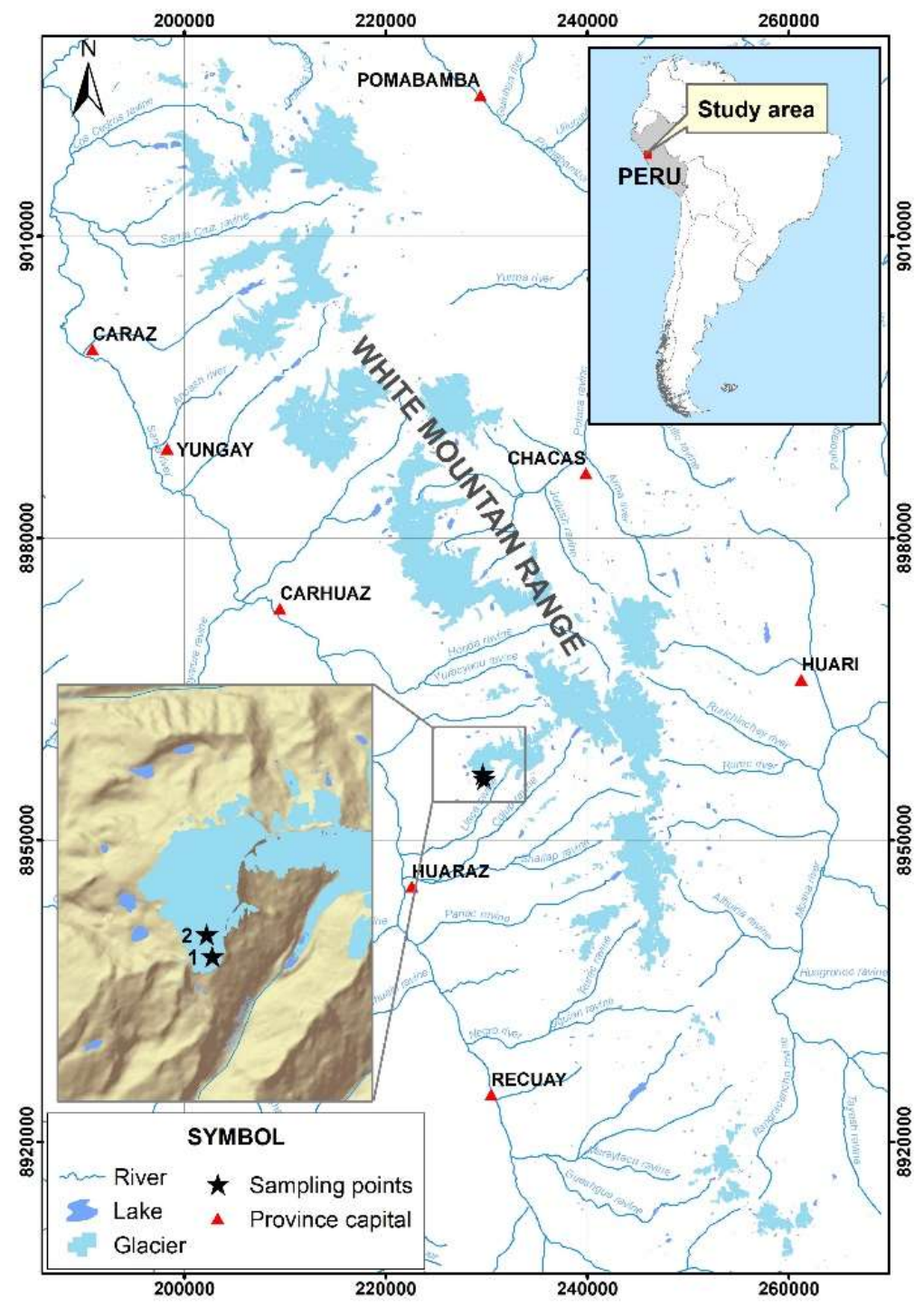

Figure 1. Sampling site in the Vallunaraju glacier, Cordillera Blanca, Peru.

\subsection{Analytical Methods}

\subsubsection{Light Absorbing Heating Method}

In this study, the Light Absoption Heating Method (LAHM) instrument was used to estimate effective black carbon (eBC). A previous study details the technique and the eBC results obtained in various glaciers in the Cordillera Blanca [17]. Briefly, LAHM is based on the absorption of light by the $\mathrm{BC}$ in the thermal infrared wavelength range, especially in the visible range. The particles retained in a filter are exposed to visible light and the increase in temperature is recorded using a digital thermometer connected to the Arduino 1.6.5 Software. Filters with a higher BC particle charge heat up faster, while filters with a lower charge maintain a temperature similar to the initial one. However, due to the variability of the mass absorption cross section (MAC) of different particles. For this reason, the LAHM result is assumed to be the eBC, representing a light absorption unit (rather than a mass of BC). The instrument was calibrated using fullerene carbon [22].

The LAHM technique is based on determining the effect of BC on the energy budget of the snow surface and providing a measure of absorption [23]. Results from the LAHM technique are compared to SP2 refractory black carbon ( $\mathrm{rBC}$ ) [22] mass concentration measurements. The SP2 rBC values were 
higher than the eBC values obtained in LAHM. However, the results are highly correlated $\left(\mathrm{R}^{2}=0.92\right)$. The slight variability could be due to unevenness in snow, as the LAHM technique uses much more snow than SP2 (600 $\mathrm{g}$ for LAHM vs. $10 \mathrm{~g}$ for SP2) [24].

\subsubsection{Albedo and trajectory model}

The SNICAR model (Snow, Ice and Aerosol Radiation) was used to estimate the reduction of snow albedo due to the presence of $\mathrm{BC}[13,25]$. This model yields the $\mathrm{BC}$ radiative forcing on snow from the input of the concentrations of BC. Other necessary data are the size of the snow grains, the thickness and density of the snow cover, and the zenith angle. In addition, it allows entering different sizes of dust particles and the concentration of volcanic ash. These last parameters were not considered in this study, because the size or type of dust present in the filter was not evaluated.

In order to estimate the provenance of BC on the Vallunaraju Glacier, the Hybrid Single Particle Lagrangian Integrated (HYSPLIT) [20] model was used. For this, a backward path direction of 72 hours was chosen considering BC short atmospheric residence time. Regarding the elevation of the trajectories, the altitudinal location of the glacier was taken as a reference, for this purpose the altitudes of 4500, 5000 and 5500 meters above sea level were considered, under a vertical speed model.

\section{Results and Discussions}

\section{1. eBC measurements in snow}

The eBC in the surface snow of the Vallunraraju Glacier in the accumulation and ablation zones was determined using the LAHM instrument [17]. The results are expressed in $\mathrm{ng} / \mathrm{g}$ and $\mu \mathrm{g} / \mathrm{cm}^{2}$, which represents the three-dimensional (volume) and two-dimensional (surface) amount of eBC, respectively. The value resulting from the analysis must be considered as effective black carbon (eBC), since it represents the same amount of carbon fullerene that effectively absorbs light.

To calculate the eBC value in a three-dimensional way:

$$
e B C_{\text {sub }}=1000 *\left(\frac{X_{\text {sub }}}{V_{\text {sub }}}\right)
$$

To calculate the eBC value in a two-dimensional way:

$$
e B C_{s f c}=\left[X_{s f c}-\left(e B C_{s u b} * \frac{V_{s f c}}{1000}\right)\right] /\left[\mathrm{A} *\left(\frac{V_{s f c}}{V_{s f c t}}\right)\right]
$$

Where $X_{s u b}$ and $X_{s f c}$ represent the amount of black carbon in micrograms $(\mu \mathrm{g})$ present in the subsurface $(2-8 \mathrm{~cm})$ and the surface $(0-2 \mathrm{~cm})$ of the snow cover, respectively. Both data are determined using the LAHM 6.1 technique instrument. $V_{s u b}$ and $V_{s f c}$ are the volumes of water in milliliters (ml) filtered to obtain the subsurface and surface filters, respectively. $V_{s f c t}$ is the total volume of filtered water to obtain the surface filter. Commonly, this is the same value as $V_{s f c}$, unless the filter is saturated and there is still water to filter. Then, the total melted water in the sample bag was measured. A is the area $\left(\mathrm{cm}^{2}\right)$ where the samples were collected $(30 \times 30 \mathrm{~cm})$. Finally, $e B C_{s u b}$ is the amount of effective black carbon in nanograms per gram of snow $(\mathrm{ng} / \mathrm{g})$ and $e B C_{s f c}$ is the effective black carbon present in the snow cover in micrograms per square centimeter $\left(\mu \mathrm{g} / \mathrm{cm}^{2}\right)$.

Variations of eBC in snow are largely due to the season of the year, with high concentrations during the dry season (May-October), and minimal during the wet season (November-April). Unlike the historical analysis of eBC from ice cores, the surface snow allows estimating the deposition of BC in a more recent time. In Figure 2 the LAHM results are shown, the three-dimensional analysis shows maximums of $214.13 \mathrm{ng} / \mathrm{g}$ and $181.60 \mathrm{ng} / \mathrm{g}$, in the accumulation and ablation zones, in September and October, respectively. In contrast, the minimum values of eBC were $3.73 \mathrm{ng} / \mathrm{g}$ and $4.23 \mathrm{ng} / \mathrm{g}$, in March (peak of the rainy season). Previously, Sánchez and Schmitt (2018) found a maximum of $780.67 \mathrm{ng} / \mathrm{g}$ and minimum of $1.89 \mathrm{ng} / \mathrm{g}$ in July and March, respectively. The annual average of eBC in the threedimensional accumulation zone is $64.31 \pm 36.04 \mathrm{ng} / \mathrm{g}$, while in the ablation zone it is $68.27 \pm 34.04$ $\mathrm{ng} / \mathrm{g}$. These values represent the accumulated $\mathrm{eBC}$ in a volume of snow in the week's prior sampling. Regarding the superficial deposition of $\mathrm{eBC}$ on the glacier in a two-dimensional way, an annual 
average accumulation of $0.020 \pm 0.010 \mathrm{ug} / \mathrm{cm}^{2}$ in the accumulation zone and $0.029 \pm 0.014 \mathrm{ug} / \mathrm{cm}^{2} \mathrm{in}$ the ablation zone was estimated. Reaching maximum values of $0.087 \mathrm{ug} / \mathrm{cm}^{2}$ and $0.101 \mathrm{ug} / \mathrm{cm}^{2} \mathrm{in}$ September and July, respectively; and a minimum of $0.001 \mathrm{ug} / \mathrm{cm}^{2} \mathrm{in}$ March, in the accumulation and ablation zones, respectively.

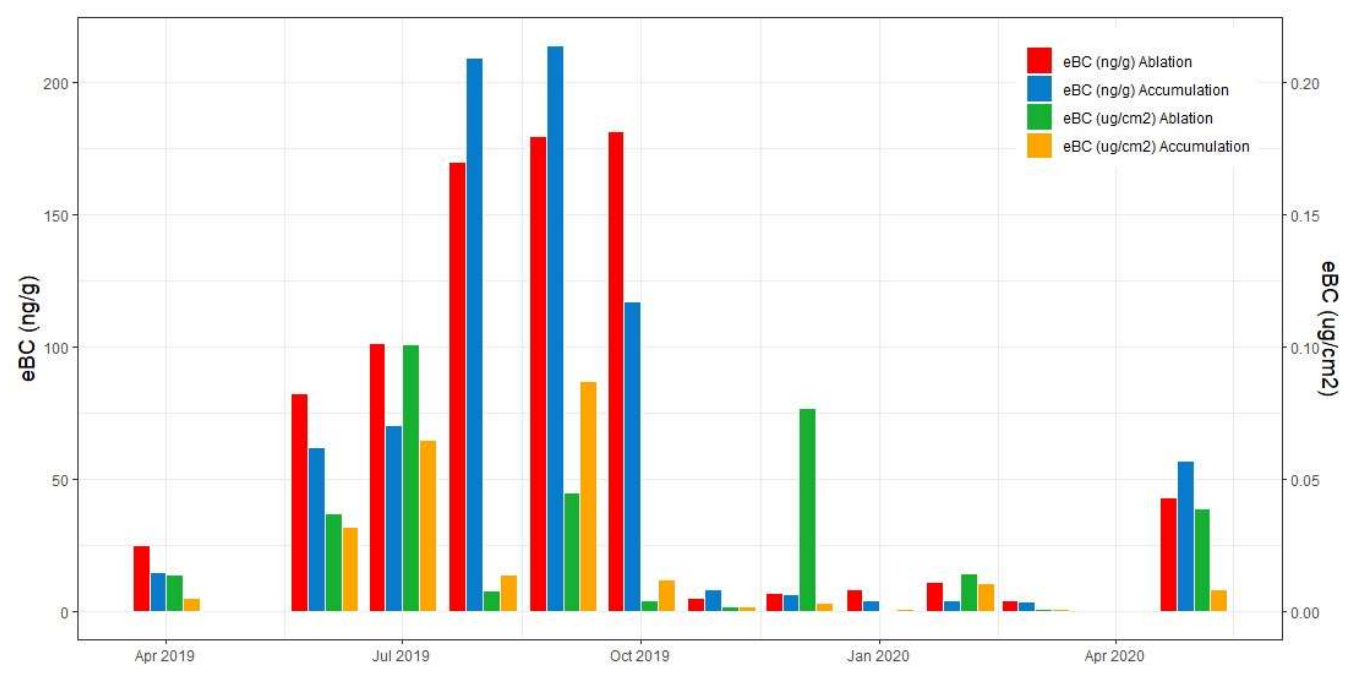

Figure 2. Shows the seasonal variability of effective black carbon in three-dimensional (ng/g) and twodimensional $\left(\mu \mathrm{g} / \mathrm{cm}^{2}\right)$ forms, in the accumulation and ablation zone of the Vallunaraju glacier.

\subsection{Albedo reduction and radiative forcing}

Snow albedo was estimated using the SNICAR simulation program, for which an initial albedo of 0.71069688 (free eBC) was considered. As eBC values were entered into SNICAR, the albedo recorded a decrease (Figure 3a). Presenting an almost perfect inverse relationship between both variables (eBC and albedo) with $\mathrm{R}^{2}=0.9785$ for the accumulation zone and with $\mathrm{R}^{2}=0.9877$ for the ablation zone. In general, albedo suffers from seasonal variability, with a significant reduction during the dry season (May-October), when black carbon deposition is greatest. While during the wet season (November-April), the carbonaceous particles function as condensation nuclei in the formation of snowflakes that cover glacial surface, increasing their ability to reflect sunlight.

The annual average of the albedo is between $0.68 \pm 0.02$ in both glaciers areas. The greatest contribution of the eBC in reducing albedo occurs during the dry season, reducing $6.36 \%$ and $6.60 \%$. While during the wet season the eBC reduces the albedo by $0.68 \%$ and $0.95 \%$ in the accumulation and ablation zone, respectively.

Regarding radiative forcing, the $\mathrm{eBC}$ is estimated to exert an average forcing of $4.52 \pm 1.84 \mathrm{~W} / \mathrm{m}^{2}$ and $4.69 \pm 1.59 \mathrm{~W} / \mathrm{m}^{2}$ during the dry season in the accumulation and ablation zone, respectively. While during the wet season the forcing is reduced to $0.49 \pm 0.27 \mathrm{~W} / \mathrm{m}^{2}$ and $0.68 \pm 0.43 \mathrm{~W} / \mathrm{m}^{2}$ in these same areas (Figure $3 b$ ). Contrary to the inverse relationship that exists between eBC and albedo, there is an almost perfect direct relationship between $\mathrm{eBC}$ and radiative forcing. These estimates are subject to various uncertainties of other impurities, the solar zenith angles and others. However, it is a close approximation of the contribution of $\mathrm{eBC}$ in radiative forcing on the recent snow cover. 


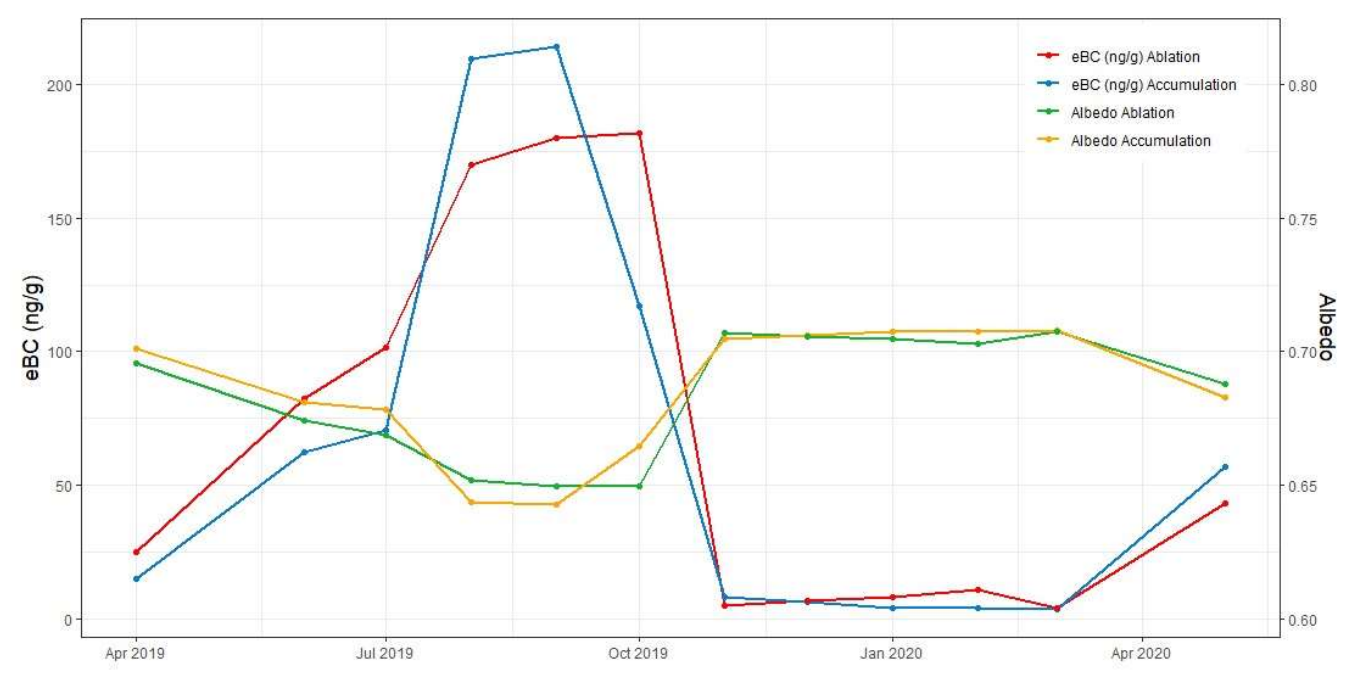

(a)

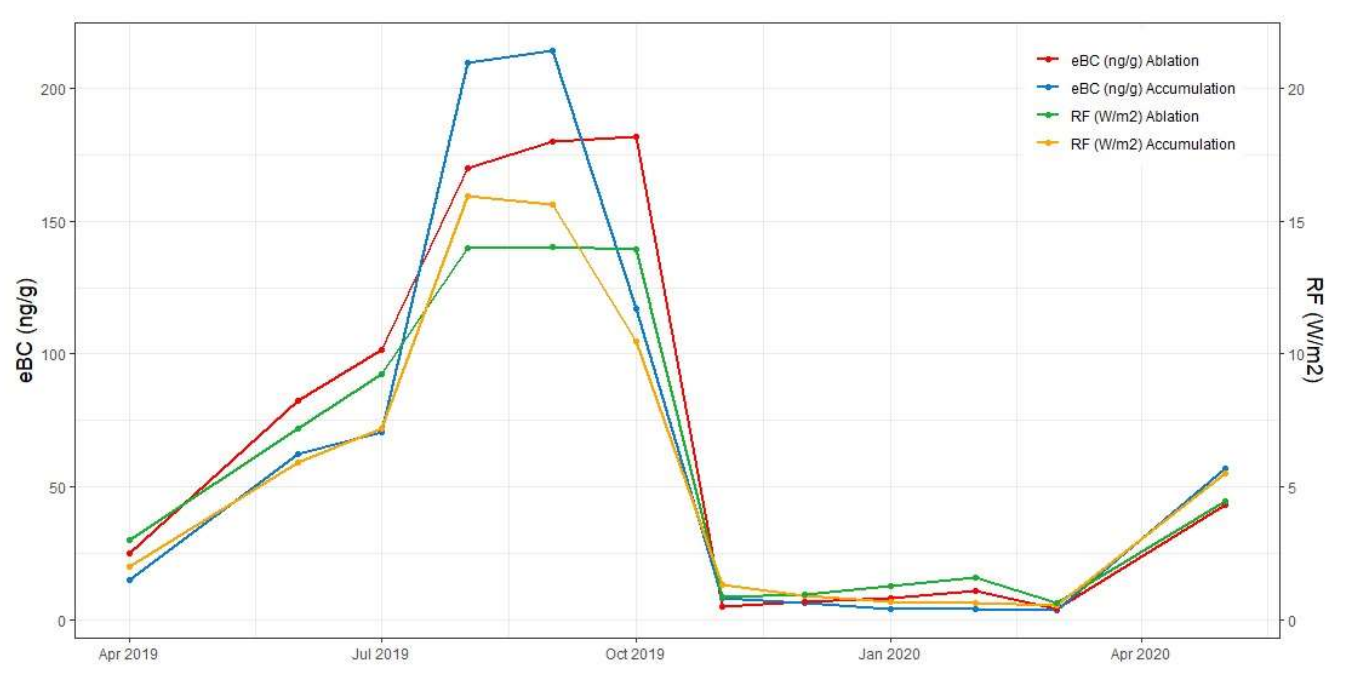

(b)

Figure 3. (a) Variation of the albedo in relation to the concentration of eBC and (b) variation of radiative forcing in relation to the concentration $\mathrm{eBC}$ in the accumulation and ablation zone of the Vallunaraju glacier.

\subsection{Surface snow melt}

The melting rate has highly significant direct relationship with the concentration of eBC $\left(\mathrm{R}^{2}=0.9843, \mathrm{P}=0.992\right.$ and $\left.\mathrm{R}^{2}=0.9936, \mathrm{P}=0.996\right)$. This indicates that a higher concentration of $\mathrm{eBC}$ corresponds to a higher melting rate (Figure 4). The ablation zone (lower part of the glacier) presents the greatest melting of snow due to the effect of the eBC. In general, the highest melting rate occurs during the dry season, with $80.18 \pm 37.30 \mathrm{~kg} / \mathrm{m}^{2}$ and $83.16 \pm 32.75 \mathrm{~kg} / \mathrm{m}^{2}$ on average. While during the wet season the melting rate is reduced to $7.91 \pm 4.29 \mathrm{~kg} / \mathrm{m}^{2}$ and $10.85 \pm 6.62 \mathrm{~kg} / \mathrm{m}^{2}$ on average, in the accumulation and ablation zone, respectively. Assuming that the snow reaches a density of $0.3 \mathrm{~g} / \mathrm{cm}^{3}$ (granular snow) during the melting process in the surface layer of the glacier, the melting is $24.05 \pm$ $9.28 \mathrm{~cm}$ and $24.95 \pm 8.32 \mathrm{~cm}$ average depth of snowmelt during dry season. While during the wet season the melting is $2.37 \pm 1.00 \mathrm{~cm}$ and $3.26 \pm 1.33 \mathrm{~cm}$ average depth of snowmelt, in the accumulation and ablation zone, respectively. 


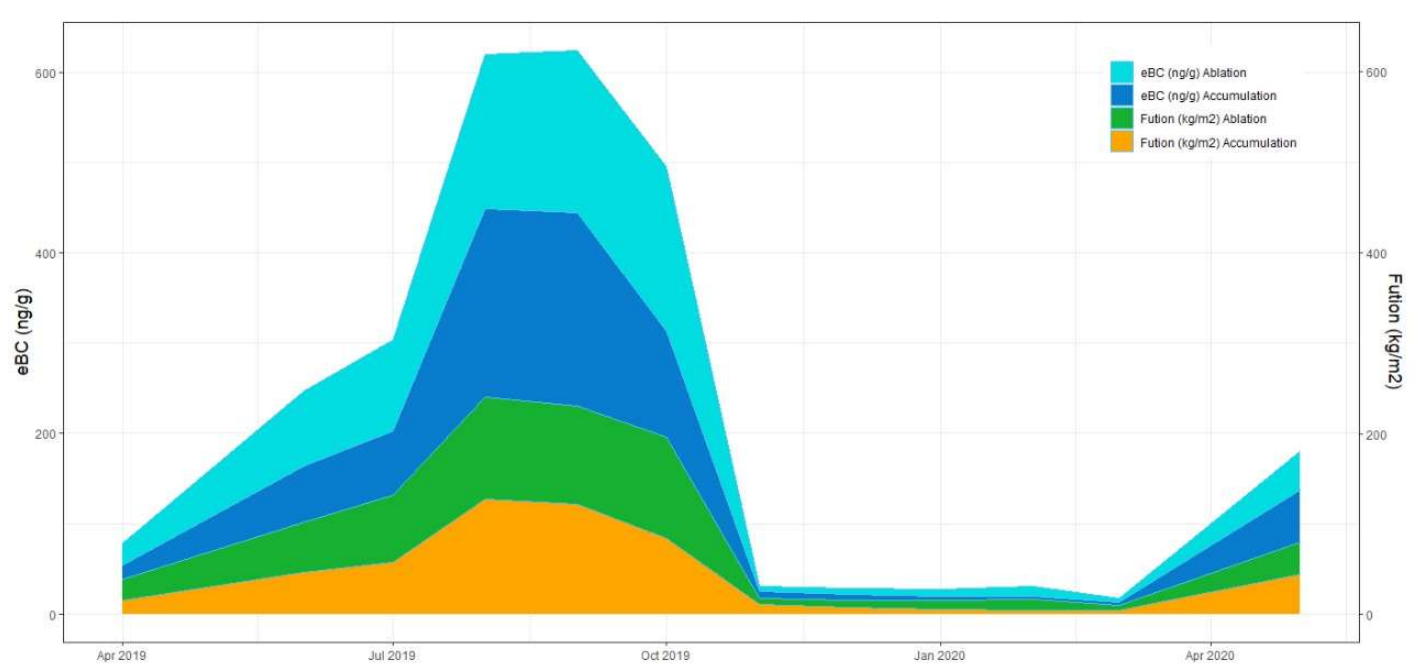

Figure 4. Variation of snow melting in relation to the concentration of eBC in the accumulation and ablation zone of the Vallunaraju glacier.

\subsection{Trajectory model and forest fire quantification}

Analysis of the three-day backward trajectories from the sampling site using the HYSPLIT model shows a predominance of east-west winds during the dry season, while winds start to converge from the southwest during the start of the wet season, originating a change of direction (northeast) during the peak and at the end of this season. The HYSPLIT results represent the average pattern of aerosol transport from possible sources during the months of study (Figure 5), and clearly shows that aerosols are carried from the Brazilian Amazon rainforest to the glacier during the dry season. A study indicates that plumes of aerosol smoke during forest fires in the Amazon can reach 3-5 km in altitude [10]. Although the Vallunaraju glacier reaches $5686 \mathrm{~m}$ a.s.l., the orographic characteristics of the Cordillera Blanca can favor the elevation of the air masses, reaching over the top of the glacier and even passing to the western flank of the mountain.

During the transition between the dry to wet season (November-December), aerosol trajectories predominate in the southwest (SW). This involves the dragging of air pollutants from the main cities of the Peruvian coast. While during the peak of the wet season the trajectories come from the central zone of Colombia (NW). It is clear that the annual prevalence of the trajectories comes from the east, dragging the aerosols from the combustion of biomass (forest fires) in the Amazon, which in turn coincides with the fire season (August-October). This would imply a substantial deposition of carbonaceous aerosols on the eastern flank of the Vallunaraju glacier. While during the wet season there is a substantial contribution of aerosols from local sources (transport, burning of agricultural residues, burning of pastures and others), which are deposited on the western flank of the glacier.

The number of forest fires at continental level (South America) was estimated using the images provided by the Visible Infrared Imaging Radiometer Suite (VIIRS), with a nominal resolution of 375 m [21]. 

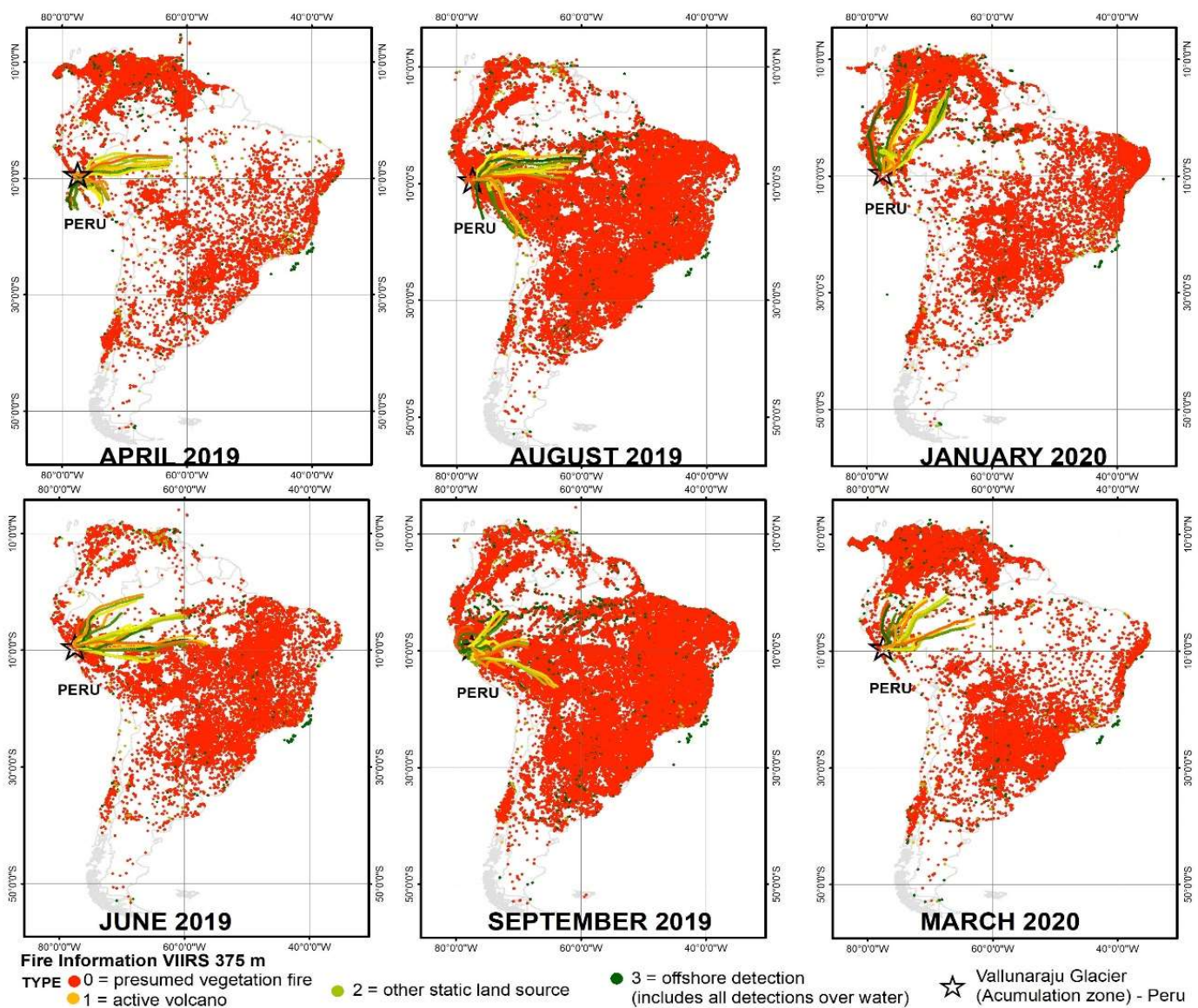

Figure 5. Aerosol trajectories towards the Vallunaraju glacier, together with the number of forest fires in the South America. It is clear that the predominance of atmospheric flow comes from the Atlantic, dragging all the aerosols emitted in the fires. It is clearly observed that in August and September the peak of forest fires is reached.

\section{Conclusions}

In a context of anthropogenic climate change, it is necessary to know all the contributors affecting accelerated glacier retreat. One of these contributors, deposited BC on the surface snow, reduces albedo and therefore accelerates snow melt. Measurement of BC over a prolonged period in surface snow is a useful mechanism to assess its seasonal variability, as well as its impacts on radiative forcing of the glacier. In this study, we analyzed the effective black carbon (eBC) present in the surface snow of the accumulation and ablation zones of the Vallunaraju glacier $\left(9^{\circ} 25^{\prime} \mathrm{S}, 77^{\circ} 27^{\prime} \mathrm{W}\right.$, $5686 \mathrm{~m}$ a.s.l.) for a period annual (April 2019-May 2020). The glacier has a strategic geographical location within the Cordillera Blanca, since it is very close to the local sources of carbonaceous aerosols. Using SNICAR model, the reduction in snow albedo and radiative forcing induced by eBC on the glacier snow were estimated. And finally, using the HYSPLIT model, the predominant trajectories for each month of sampling were evaluated based on the amount of forest fires provided by VIIRS images.

The concentration of eBC in the snow of the Vallunaraju glacier presents a marked seasonal variability, with maximum values during the dry season (May-October) and minimum values during the wet season (November-April). The albedo presents an inverse relationship with the concentration of eBC, being reduced by $6.36 \%$ and $6.60 \%$ during the dry season, and $0.68 \%$ and $0.95 \%$ during the wet season in the accumulation and ablation zones, respectively.

The HYSPLIT REANALYSIS trajectories show different patterns of aerosol circulation during the study period. Finding a marked difference between the seasons (dry and wet), with a predominance of pollutants from the Amazon rainforest (east) during the dry season, while at the 
beginning of the wet season the winds come from the southwest, originating a change of direction (northeast) during the peak and at the end of this season. This involves the dragging of atmospheric pollutants from the main cities of the Peruvian coast. Considering seasonality in the region, the greatest contribution of $\mathrm{BC}$ occurs during the dry season, when forest fires in the Amazon and the burning of pastures near the glacier are intense and numerous. VIIRS images show a fire peak in August and September in South America. The trend points to a higher occurrence of forest fires in the Amazon rainforest, this would increase the deposition of carbonaceous particles on the Andean glaciers, aggravating the process of melting of seasonal snow.

Author Contributions: Conceptualization, W.S.; methodology, C.S. and W.S.; software, A.S., C.S. and W.S.; validation, C.S.; formal analysis, W.S., A.S and G.M.; investigation, W.S.; resources, C.S. and W.S.; data curation, W.S., G.M; writing - original draft preparation, W.S.; writing - review and editing, W.S. and C.S.; supervision, C.S.; project administration, W.S.; funding acquisition, W.S. All authors have read and agreed to the published version of the manuscript.

Funding: This research was funded by The American Alpine Club, through an annual research grant. (https://americanalpineclub.org/press-releases-1/2019-research-grants)

Acknowledgments: We thank the Glaciology and Water Resources Unit of the National Water Authority of Peru for providing the solar radiation data.

Conflicts of Interest: The authors declare no conflict of interest.

\section{References}

1. Matsui, H., Hamilton, D. S., \& Mahowald, N. M. (2018). Black carbon radiative effects highly sensitive to emitted particle size when resolving mixing-state diversity. Nature Communications, 9(1), 3446. https://doi.org/10.1038/s41467-018-05635-1

2. Doherty, S. J., Steele, M., Rigor, I., \& Warren, S. G. (2015). Interannual variations of light-absorbing particles in snow on Arctic sea ice: BC IN SNOW ON ARCTIC SEA ICE. Journal of Geophysical Research: Atmospheres, 120(21), 11,391-11,400. https://doi.org/10.1002/2015JD024018

3. Wang, X., Doherty, S. J., \& Huang, J. (2013). Black carbon and other light-absorbing impurities in snow across Northern China: LIGHT-ABSORBING IMPURITIES IN SNOW. Journal of Geophysical Research: Atmospheres, 118(3), 1471-1492. https://doi.org/10.1029/2012JD018291

4. Bond, T. C., Doherty, S. J., Fahey, D. W., Forster, P. M., Berntsen, T., DeAngelo, B. J., Flanner, M. G., Ghan, S., Kärcher, B., Koch, D., Kinne, S., Kondo, Y., Quinn, P. K., Sarofim, M. C., Schultz, M. G., Schulz, M., Venkataraman, C., Zhang, H., Zhang, S., ... Zender, C. S. (2013). Bounding the role of black carbon in the climate system: A scientific assessment: BLACK CARBON IN THE CLIMATE SYSTEM. Journal of Geophysical Research: Atmospheres, 118(11), 5380-5552. https://doi.org/10.1002/jgrd.50171

5. Delaney, I., Kaspari, S., \& Jenkins, M. (2015). Black carbon concentrations in snow at Tronsen Meadow in Central Washington from 2012 to 2013: Temporal and spatial variations and the role of local forest fire activity. Journal of Geophysical Research: Atmospheres, 120(18), 9160-9172. https://doi.org/10.1002/2015JD023762

6. Menon, S., Koch, D., Beig, G., Sahu, S., Fasullo, J., \& Orlikowski, D. (2010). Black carbon aerosols and the third polar ice cap. Atmospheric Chemistry and Physics, 10(10), 4559-4571. https://doi.org/10.5194/acp-104559-2010

7. Li, J., Jiang, L., Chen, C., Liu, D., Du, S., Zhang, Y., Yang, Y., \& Tang, L. (2020). Characteristics and Sources of Black Carbon Aerosol in a Mega-City in the Western Yangtze River Delta, China. Atmosphere, 11(4), 315. https://doi.org/10.3390/atmos11040315

8. Magalhães, N. de, Evangelista, H., Condom, T., Rabatel, A., \& Ginot, P. (2019). Amazonian Biomass Burning Enhances Tropical Andean Glaciers Melting. Scientific Reports, 9(1), 16914. https://doi.org/10.1038/s41598-019-53284-1

9. Martin, S. T., Andreae, M. O., Artaxo, P., Baumgardner, D., Chen, Q., Goldstein, A. H., Guenther, A., Heald, C. L., Mayol-Bracero, O. L., McMurry, P. H., Pauliquevis, T., Pöschl, U., Prather, K. A., Roberts, G. C., Saleska, S. R., Silva Dias, M. A., Spracklen, D. V., Swietlicki, E., \& Trebs, I. (2010). Sources and properties of Amazonian aerosol particles. Reviews of Geophysics, 48(2), RG2002. https://doi.org/10.1029/2008RG000280

10. Baars, H., Ansmann, A., Althausen, D., Engelmann, R., Heese, B., Müller, D., Artaxo, P., Paixao, M., Pauliquevis, T., \& Souza, R. (2012). Aerosol profiling with lidar in the Amazon Basin during the wet and 
dry season: AEROSOL PROFILING IN AMAZONIA. Journal of Geophysical Research: Atmospheres, 117(D21), n/a-n/a. https://doi.org/10.1029/2012JD018338

11. Rabatel, A., Francou, B., Soruco, A., Gomez, J., Cáceres, B., Ceballos, J. L., Basantes, R., Vuille, M., Sicart, J.E., Huggel, C., Scheel, M., Lejeune, Y., Arnaud, Y., Collet, M., Condom, T., Consoli, G., Favier, V., Jomelli, V., Galarraga, R., ... Wagnon, P. (2013). Current state of glaciers in the tropical Andes: A multi-century perspective on glacier evolution and climate change. The Cryosphere, 7(1), 81-102. https://doi.org/10.5194/tc-7-81-2013

12. Bradley, R. S. (2004). Projected temperature changes along the American cordillera and the planned GCOS network. Geophysical Research Letters, 31(16), L16210. https://doi.org/10.1029/2004GL020229

13. Flanner, Mark G., Zender, C. S., Randerson, J. T., \& Rasch, P. J. (2007). Present-day climate forcing and response from black carbon in snow. Journal of Geophysical Research, 112(D11), D11202. https://doi.org/10.1029/2006JD008003

14. McConnell, J. R., Edwards, R., Kok, G. L., Flanner, M. G., Zender, C. S., Saltzman, E. S., Banta, J. R., Pasteris, D. R., Carter, M. M., \& Kahl, J. D. W. (2007). 20th-Century Industrial Black Carbon Emissions Altered Arctic Climate Forcing. Science, 317(5843), 1381-1384. https://doi.org/10.1126/science.1144856

15. Ming, J., Cachier, H., Xiao, C., Qin, D., Kang, S., Hou, S., \& Xu, J. (2008). Black carbon record based on a shallow Himalayan ice core and its climatic implications. Atmospheric Chemistry and Physics, 8(5), 13431352. https://doi.org/10.5194/acp-8-1343-2008

16. Xu, B., Cao, J., Hansen, J., Yao, T., Joswia, D. R., Wang, N., Wu, G., Wang, M., Zhao, H., Yang, W., Liu, X., \& He, J. (2009). Black soot and the survival of Tibetan glaciers. Proceedings of the National Academy of Sciences, 106(52), 22114-22118. https://doi.org/10.1073/pnas.0910444106

17. Schmitt, C. G., All, J. D., Schwarz, J. P., Arnott, W. P., Cole, R. J., Lapham, E., \& Celestian, A. (2015). Measurements of light-absorbing particles on the glaciers in the Cordillera Blanca, Peru. The Cryosphere, 9(1), 331-340. https://doi.org/10.5194/tc-9-331-2015

18. Revista de Glaciares y Ecosistemas de Montañas by INAIGEM - issuu. (s. f.). Recuperado 28 de septiembre de 2020, de https://issuu.com/inaigem/docs/inaigem_docs_revista_inaigem_no._4

19. Rolph, G., Stein, A., \& Stunder, B. (2017). Real-time Environmental Applications and Display sYstem: READY. Environmental Modelling \& Software, 95, 210-228. https://doi.org/10.1016/j.envsoft.2017.06.025

20. Stein, A. F., Draxler, R. R., Rolph, G. D., Stunder, B. J. B., Cohen, M. D., \& Ngan, F. (2015). NOAA's HYSPLIT Atmospheric Transport and Dispersion Modeling System. Bulletin of the American Meteorological Society, 96(12), 2059-2077. https://doi.org/10.1175/BAMS-D-14-00110.1

21. Giglio, L., Csiszar, I., \& Justice, C. O. (2006). Global distribution and seasonality of active fires as observed with the Terra and Aqua Moderate Resolution Imaging Spectroradiometer (MODIS) sensors: GLOBAL FIRE DISTRIBUTION AND SEASONALITY. Journal of Geophysical Research: Biogeosciences, 111(G2), n/a-n/a. https://doi.org/10.1029/2005JG000142

22. Baumgardner, D., Popovicheva, O., Allan, J., Bernardoni, V., Cao, J., Cavalli, F., Cozic, J., Diapouli, E., Eleftheriadis, K., Genberg, P. J., Gonzalez, C., Gysel, M., John, A., Kirchstetter, T. W., Kuhlbusch, T. A. J., Laborde, M., Lack, D., Müller, T., Niessner, R., ... Viana, M. (2012). Soot Reference Materials for instrument calibration and intercomparisons: A workshop summary with recommendations. Atmospheric Measurement Techniques Discussions, 5(2), 2315-2362. https://doi.org/10.5194/amtd-5-2315-2012

23. Grenfell, T. C., Doherty, S. J., Clarke, A. D., \& Warren, S. G. (2011). Light absorption from particulate impurities in snow and ice determined by spectrophotometric analysis of filters. Applied Optics, 50(14), 2037. https://doi.org/10.1364/AO.50.002037

24. Khan, A. L., Dierssen, H., Schwarz, J. P., Schmitt, C., Chlus, A., Hermanson, M., Painter, T. H., \& McKnight, D. M. (2017). Impacts of coal dust from an active mine on the spectral reflectance of Arctic surface snow in Svalbard, Norway. Journal of Geophysical Research: Atmospheres, 122(3), 1767-1778. https://doi.org/10.1002/2016JD025757

25. Flanner, M. G., Zender, C. S., Hess, P. G., Mahowald, N. M., Painter, T. H., Ramanathan, V., \& Rasch, P. J. (2009). Springtime warming and reduced snow cover from carbonaceous particles. Atmospheric Chemistry and Physics, 9(7), 2481-2497. https://doi.org/10.5194/acp-9-2481-2009 